\title{
Physicochemical Characterization of Municipal Solid Waste in Sawla town, Gofa Zone, Ethiopia
}

\author{
${ }^{* 1}$ HAILE, MZ; ${ }^{1}$ MOHAMMED, ET; ${ }^{2}$ GEBRETSADIK, FD \\ ${ }^{*}$ Chemistry Department, College of Natural and Computational Science, Hawassa University, Hawassa, Ethiopia. \\ ${ }^{2}$ Duza Meles Zenawi Secondary School, Sawla Town Administration, Gofa Zone, SNNPR, Ethiopia. \\ *Corresponding Author Email: melerevised@gmail.com,Tel: +251)912371675; other Author Emails:endale1998@yahoo.com; Tel: \\ +251)934128175; firewdejeneg@gmail.com; +251)910862622
}

\begin{abstract}
To design and develop integrated waste management systems, it is necessary to have information about the physical and chemical characteristics of the household's municipal solid waste (MSW). The study aims to characterize the physicochemical composition of MSW in Sawla town, Ethiopia using structured questionnaire and field observation to obtain data on the socio-economic condition and current MSW management practices of the residents. The data showed that, the town has no sanitary landfill. The per capita daily SW generation for $\mathrm{HH}$ range $0.21-1.02 \mathrm{~kg} / \mathrm{capita} / \mathrm{day}$ with mean value of $0.51 \mathrm{~kg} / \mathrm{capita} /$ day. Regarding its chemical characteristics, the HHMSW was composed of main food and organic waste $(34.81 \%)$ and ash- dust (49.45\%). The remaining $6.08 \%$ of plastic, $3.87 \%$ glass, $3.51 \%$ of paper and $2.28 \%$ of metal waste. The mean percentage moisture content, volatile matter content, ash content and fixed carbon content of the MSW were $25.57 \%, 28.09 \%, 32.03 \%$, and $14.32 \%$ respectively. The mean density, $\mathrm{pH}$ and fusing point of ash for the MSW were $613.22 \mathrm{~kg} / \mathrm{m} 3,10.657$ and $965{ }^{\circ} \mathrm{C}$ respectively. Using AAS, the concentration of heavy metals $\mathrm{Cu}, \mathrm{Pb}, \mathrm{Zn}$, $\mathrm{Co}, \mathrm{Cd}$, and $\mathrm{Cr}$ were determined and the result was $2.59,7.12,293.39$ and $0.125 \mathrm{mg} / \mathrm{kg}$ for $\mathrm{Cu}, \mathrm{Pb}, \mathrm{Zn}$, and Co respectively. The concentration of $\mathrm{Cd}$ and $\mathrm{Cr}$ was not detected. In conclusion, the best ways to tackle the problems related to MSWM practices of residents are: improving the institutional structure and budget allocation of the SBD, the involvement of stakeholders in SWM practices, implementation of sustainable SWM practices through awareness creation and training and implementation of rules and regulations. The result of this study suggests that biodegradable SW constituted a lion share of the SW generated in the town. Thus, the municipality can recover this organic fraction by introducing integrated urban agriculture that might convert this waste to organic fertilizer through composting.
\end{abstract}

\section{DOI: https://dx.doi.org/10.4314/jasem.v23i11.19}

Copyright: Copyright $($ C 2019 Haile et al. This is an open access article distributed under the Creative Commons Attribution License (CCL), which permits unrestricted use, distribution, and reproduction in any medium, provided the original work is properly cited.

Dates: Received: 07 October 2019; Revised: 11 November 2019; 24 November 2019

Keywords: Solid waste, waste characterization, proximate analysis, heavy metal

Solid waste management (SWM) is defined as the collection, transportation, processing, recycling, and disposal of SW materials to reduce their effect on health, environment, and aesthetics (Solomon, 2011). A more comprehensive definition has been provided by Tchobanoglous et al., (1993), which states that SWM is: the discipline associated with the control of generation, storage, collection, transfer, processing, and disposal of SW in a way which is governed by the best principles of health, economics, engineering, aesthetics, and other environmental considerations and that is also responsive to public attitudes. SWM practices are essential components of environmental infrastructure in human settlement. These practices encompass all activities undertaken from the point of waste generation up to the final disposal. Solid waste (SW) generation is an inevitable consequence of production and consumption activities in any economy (UNEP, 2005) and the waste generators comprise households (HHs), industries, hospitals and commercial and administrative establishments. The amount and type of waste generated are greatly influenced by geographical and socioeconomic factors include; HH size, household income, waste collection frequency and characteristics of the source area (Rush brook and Pugh, 1999). SW handling comprises activities associated with managing wastes until they are placed in the containers used for their storage, before collection or return to recycling centers (Tchobanoglous et al., 1993). The specific activities associated with handling waste material at the source of generation will vary depending on the types of waste materials that are separated for reuse and the extent to which these materials are separated from the waste stream. Storage of SW refers to the place where the generated solid waste is stored until it is collected (Tchobanoglous et al., 1993). Factors such as type of container, container location and the contamination of waste components affect the storage of putrescible materials which decompose rapidly and hence must be collected quickly (Solomon, 2011). The collection of $\mathrm{SW}$ involves the process of picking up wastes from collection points, loading them into a vehicle and transporting to the disposal site. Disposal of SW is the 
final element in the SW process. Similarly, the current condition of municipal solid waste management services in different towns of Ethiopia is also becoming a challenge for municipalities. For instance, according to Birke's (1999) cited in Degnet (2003) study of municipal solid waste management practices of 15 regional cities of Ethiopia, a controlled solid waste disposal system was practiced in only two of them. That means small proportions of the urban dwellers are served and a large quantity of solid waste left uncollected. Also, a study conducted by Minister of Health (MoH), 1996 cited in Gebrie (2009) revealed the percentage of solid wastes that are left uncollected and disposed of anywhere without due attention regarding their consequences in different towns of Ethiopia. SWM in Sawla town municipality corresponds to a collection and disposal system managed by the town Sanitation and Beautification Directorate (SBD). Based on data provided by the directorate, MSW is collected and disposed of in a dumpsite. However, SW is seen on the streets, open areas, in gullies, and river courses of the town. So the study focused on assessing the waste generation, composition, physical and chemical characterization of HHs, which could be used as inputs in developing plans for efficient waste collection, recycling, and disposal program for sustainable development. Hence, the specific objectives of the study includes obtaining solid waste generation data from the selected households in Sawla town and their generation rate, estimation of the average daily generation rate ( $\mathrm{kg}$ /day) per-capita, per $\mathrm{HH}$ and town, identification and categorization of waste compositions, determination of the relationship between a social class and the amount and type of SW generation, characterization of the physicochemical composition of SW from HHs in Sawla town.

\section{MATERIALS AND METHODS}

The study was conducted in the Sawla town which is the capital city of the Gofa zone in SNNPR. It is far away from Addis Ababa and the regional center Hawassa in 514 and 258 kilometers respectively. It is located at the South West of Hawassa and North West of Arbaminch as shown in Figure 1. The area geographically lies between $6^{\circ} 15^{\prime}-6^{\circ} 20^{\prime} \mathrm{N}$ and $36^{\circ} 51^{\prime}-36^{\circ} 56^{\prime} \mathrm{E}$ with an average altitude of 1547 meters above sea level. It constitutes an area of 4863 hectares. There are two sub-cities, namely "YochaSawla" and "Bola Sawla" sub-city and 9 Kebeles. The town shares common borders with ZalaWoreda in the east, Geze Gofa Woreda in the west, Demba Gofa in the north and Demba Gofa and Oyda Woreda in the south.Sawla has a Municipal Sanitation and Beautification Department (SBD) that is responsible for all aspects of SWM.

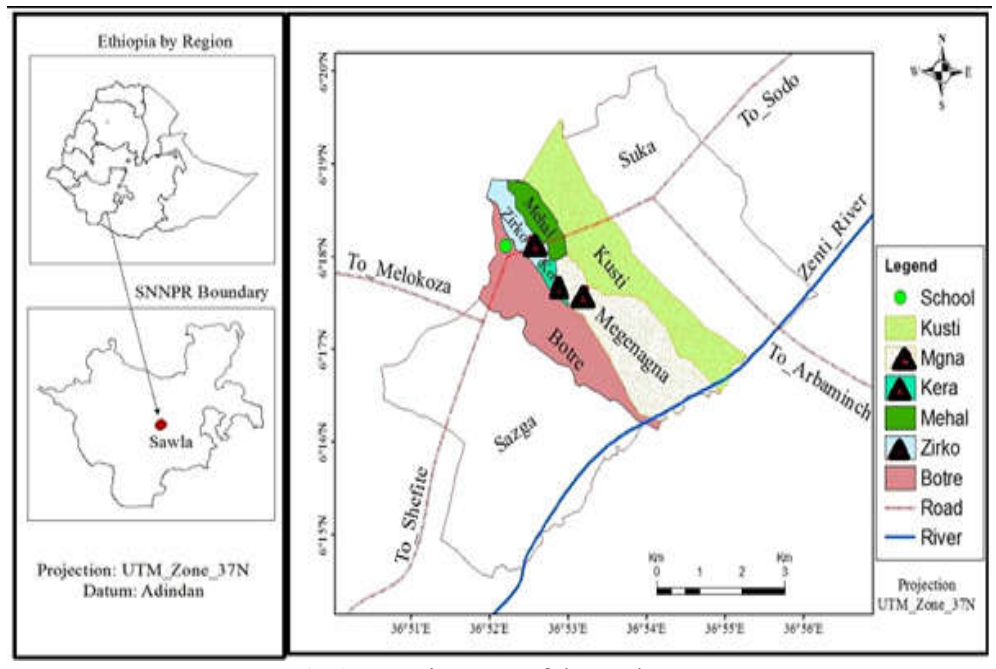

Fig 1: Location map of the study area

Sampling, Sample preparation and Analysis: In this study, descriptive survey method was used to get qualitative and quantitative data that include socioeconomic characteristics of the HHS and investigate the attitude of the HHS towards SWM practices (Afewerk and Beneberu, 2015). Six urban Kebeles' were classified into three separate groups based on distance from Sawla town center, population density, infrastructure, and geographical location and then one Kebele was selected from each group using a random sampling method. Participatory houses were identified by classifying the houses into three income groups as low, middle and high-income groups. 80\% HHs were selected from low income, $10 \%$ from middle income and 10\% from high-income level since the majority of the population in Sawla town has low 
income. The structured questionnaire and oral interview were used for the selected residential housing units in the three selected Kebeles of Sawla town in order to have information about the type of most abundant SW generated in at $\mathrm{HH}$ level, constituents of SW, separation of SW, onsite SW handling, mode of SW disposal practices, cost of disposal and other activities. Collection of information extended for twelve consecutive days. Field observation for understanding the generation, composition, handling and illegal dumping practices of MSW in different residential areas and on the streets. During this observation, the researcher focused on the collection, storage, transport and disposal site facilities of SW in Sawla town. A direct method of SW accumulation and the level of SWM program assessment were carried out by gathering information from residents, observation of the area.

Physical Characterization of MS: The sampled HHs were thought to put SW separately in the different plastic bags given. The mixed SWs in some sampled HHs were opened onto the plastic sheet and separated into different types as food waste, paper/cardboard, plastics/rubber, glass/ceramics, metals, and ash/dust. Each category was weighed by using movable hand balance and recorded in the datasheet by the researcher and research assistant before the house to house SW collectors come to take the SW Physical composition calculation was done for a sample of solid waste to identify percentage by weight as described by Lemma (2007).

Chemical Characterization of MSW: Since the waste is heterogeneous with no additional information available on chemical properties, three points were located on the landfill site and SW with the total mass of $5.4 \mathrm{~kg}$ was taken by digging an area with a volume of $0.0045 \mathrm{~m}^{3}(15 \mathrm{~cm}, 15 \mathrm{~cm}$ and $20 \mathrm{~cm}$ of length, width, and depth respectively) at each point. The SW sample was homogenized following the Mexican Standard Test Method "NMX-AA-015-1985" (SCOFI 1985c). Only glass and metals were not included since they interfere with thermal treatment. Dividing the sample into four portions and by discarding two portions, approximately $3 \mathrm{~kg}$ of the homogenized SW sample was taken, shredded and ground to make it representative. The sample was then properly preserved, stored and prepared for subsequent analysis. Heavy metals such as $\mathrm{Mn}, \mathrm{Cu}, \mathrm{Pb}, \mathrm{Zn}, \mathrm{Co}$, $\mathrm{Cd}$ and $\mathrm{Cr}$ were determined using atomic absorption spectrophotometer (Buck Scientific, Model 210 VGP Atomic absorption spectrophotometer, USA) using wet and dry digestion methods. The analysis of moisture content, ash content, volatile matter content, fusing point of ash, heating (calorific) value and $\mathrm{pH}$ of the SW were carried out using ASTM Standard D 5231-5292.

Data Analysis Technique: Administered questionnaires will be processed to check completeness, accuracy, and consistency of responses to check out and remove errors. Data analysis was carried out by using Excel and SPSS software. Data obtained from primary, secondary sources and the laboratory will be analyzed by combining the information collected by using simple descriptive statistics by both qualitative and quantitative techniques. Quantitative data includes percentages, graphical maps, charts, and tabular form. The average SW generation rate was calculated for different HHs in terms of income level and family size. The existence of any variation among respondents, percentage, frequency, ratio, correlation and one way ANOVA test was carried out. Also, the data collected from direct physical observation or visualization was analyzed by describing the phenomena using personal judgment and supported by photographs.

\section{RESULTS AND DISCUSSION}

Physical Characterization of $S W$ : The result of the physical composition of the SW was indicated in Figure 2. So $49.45 \%$ of SW generated in Sawla town was composed of ash and dust and $34.81 \%$ was food and organic waste. This means that about $84.53 \%$ of the MSW in the town was composed of food-organic waste and ash-dust waste that might be due to the use of firewood as energy source in almost all of the HHs. Compared to the developed countries, wastes generated in the study area contain large volumes of organic matter.

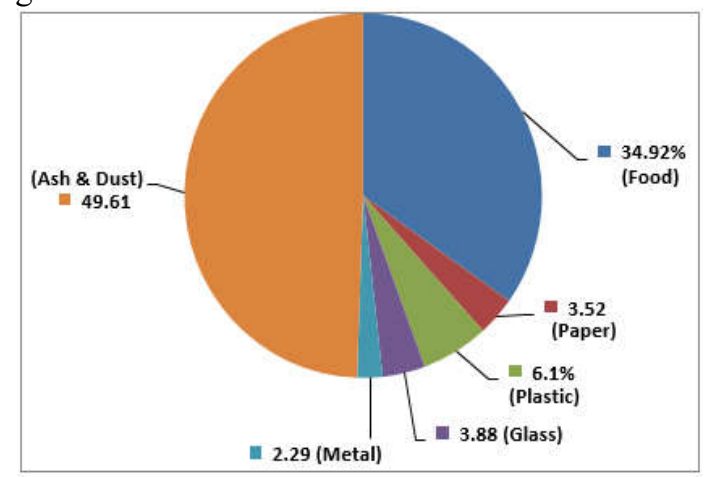

Fig 2: Types of HHs SW by weight

Determination of $S W$ generation rate per $H H$ per Kg/Daily/Weekly/Monthly/Yearly: The daily SW generation per $\mathrm{HH}$ (PDPHH) of Sawla town was obtained by dividing the total average SW generated per week per $\mathrm{HH}$ by the total number of HHs. The monthly (PMPHH) and yearly (PYPHH) average SW was estimated by multiplying PDPHH SW by 30 and 
365 respectively. The result of the study is presented in Table 1 and it showed that the SW generation rate per $\mathrm{HH}$ of Sawla town was $2.17 \mathrm{~kg} / \mathrm{HH} /$ day, 15.20 $\mathrm{kg} / \mathrm{HH} /$ week, $65.13 \mathrm{~kg} / \mathrm{HH} /$ month and $792.42 \mathrm{~kg} /$ $\mathrm{HH} /$ year.

\begin{tabular}{|c|c|c|c|c|c|}
\hline $\begin{array}{l}\text { Type of } \\
\text { SW }\end{array}$ & $\begin{array}{l}\text { Total sum }(T) \\
=S_{1}+S_{2}+\cdot \cdot \\
\cdot+S_{133}\end{array}$ & $\begin{array}{l}\text { PDPHH } \\
=\frac{T}{(7 \times 133)}\end{array}$ & $\begin{array}{l}P W P H H \\
=\frac{T}{133}\end{array}$ & $\begin{array}{l}\text { PMPHH } \\
=(\text { PDPHH }) \\
\times \mathbf{3 0}\end{array}$ & $\begin{array}{l}\text { PYPHH } \\
=(\text { PDPHH }) \\
\times 365\end{array}$ \\
\hline Food & 705.80 & 0.76 & 5.31 & 22.74 & 276.71 \\
\hline Paper & 71.18 & 0.08 & 0.54 & 2.29 & 27.91 \\
\hline Plastic & 123.22 & 0.13 & 0.93 & 3.97 & 48.31 \\
\hline Glass & 78.49 & 0.08 & 0.59 & 2.53 & 30.77 \\
\hline Metal & 46.32 & 0.05 & 0.35 & 1.49 & 18.16 \\
\hline Ash-Dust & 1002.82 & 1.08 & 7.54 & 32.31 & 393.16 \\
\hline Sum & 2021.22 & 2.17 & 15.23 & 65.13 & 793.22 \\
\hline
\end{tabular}

Determination of $S W$ generation rate per capita per Kg/Daily/Weekly/Monthly/Yearly: Per capita per day SW generation rate (PCPDSWGR) per $\mathrm{kg}$ of Sawla town was obtained by dividing PDPHH per $\mathrm{kg}$ by

Table 2: SW generation rate per capita

\begin{tabular}{|c|c|c|c|c|}
\hline Type of SW & $\begin{array}{l}\text { PCPDSWGR } \\
=\frac{P D P H H}{4.26}\end{array}$ & $\begin{array}{l}\text { PCPWSWG } \\
=(P C P D) \times 7\end{array}$ & $\begin{array}{l}\text { PCPMSWG } \\
=(P C P D) \times 30\end{array}$ & $\begin{array}{l}\text { PCPYSWG } \\
=(P C P D) \times 365\end{array}$ \\
\hline Food & 0.18 & 1.24 & 5.34 & 64.96 \\
\hline Paper & 0.02 & 0.13 & 0.54 & 6.55 \\
\hline Plastic & 0.03 & 0.22 & 0.93 & 11.34 \\
\hline Glass & 0.02 & 0.14 & 0.59 & 7.22 \\
\hline Metal & 0.01 & 0.08 & 0.35 & 4.26 \\
\hline Ash-Dust & 0.25 & 1.77 & 7.59 & 92.29 \\
\hline Sum & 0.51 & 3.58 & 15.34 & 186.62 \\
\hline
\end{tabular}

The result showed that the average SW generated is $0.51 \mathrm{~kg} /$ capita/day; $3.58 \mathrm{~kg} / \mathrm{cap} /$ week; 15.34 $\mathrm{kg} / \mathrm{cap} / \mathrm{month}$ and $186.62 \mathrm{~kg} / \mathrm{cap} /$ year. The per capita per day SW generated in the town $(0.51 \mathrm{~kg})$ is above the range 0.17 to $0.48 \mathrm{~kg} /$ capita/ day which are the amount of SW generated in urban areas of Ethiopia (EPA/ World Bank, 2004). Furthermore, the result on the annual per-capita amount of SW generated in Sawla town, $186.62 \mathrm{~kg}$ is in the range of 109.5- 525.6 $\mathrm{kg}$ per-capita typically by developing countries (Karak, T; Bhagat, RM; and Pradip, BP (2012). average family size of the sampled HHs. The per capita per week, per month and per year generation rate were calculated as shown in Table 2 .
Determination of $S W$ Generation rate per Kg/Daily/Weekly/Monthly/Yearly: $\quad$ The total generation rate of $\mathrm{HHs} \mathrm{SW}$ in Sawla town was calculated from the average per capita generation rate (PCPDSWGR) and the total population of Sawla town. The total population of Sawla town according to the municipalities of the two sub towns namely Yocha Sawla and Bola Sawla is equal to 44,298. The estimated amount of MSW generated per day, per week, per month and year at the town level in different types was calculated as shown in Table 3.

Table 3: SW generation rate per Kg/Daily/Weekly/Monthly/Yearly

\begin{tabular}{lllll}
\hline $\begin{array}{l}\text { Type of } \\
\text { SW }\end{array}$ & $\begin{array}{l}\text { Per Day Town } \\
\text { (PCPD }) \\
\times \mathbf{4 4 , 2 9 8}\end{array}$ & $\begin{array}{l}\text { Per Week Town } \\
=(\boldsymbol{P C P D}) \\
\times \mathbf{4 4 , 2 9 8} \times \mathbf{7}\end{array}$ & $\begin{array}{l}\text { PerMonth Town } \\
=(\boldsymbol{P C P D}) \\
\times \mathbf{4 4}, \mathbf{2 9 8} \times \mathbf{3 0}\end{array}$ & $\begin{array}{l}\text { Per Year Town } \\
=(\boldsymbol{P C P D}) \\
\times \mathbf{4 4}, \mathbf{2 9 8} \times \mathbf{3 6 5}\end{array}$ \\
\hline Food & 7883.27 & 55182.90 & 236498.10 & 2877394.00 \\
Paper & 795.03 & 5565.20 & 23850.86 & 290185.50 \\
Plastic & 1376.28 & 9633.94 & 41288.33 & 502341.30 \\
Glass & 876.68 & 6136.73 & 26300.28 & 319986.80 \\
Metal & 517.36 & 3621.52 & 15520.82 & 188836.60 \\
Ash-Dust & 11200.77 & 78405.38 & 336023.10 & 4088281.00 \\
Sum & $\mathbf{2 2 6 4 9 . 3 8}$ & $\mathbf{1 5 8 5 4 5 . 6 7}$ & $\mathbf{6 7 9 4 8 1 . 5 0}$ & $\mathbf{8 2 6 7 0 2 5 . 0 0}$ \\
\hline
\end{tabular}

Relationship between family size of HHs and amount of $S W$ generated per $\mathrm{HH}$ : The family size of $\mathrm{HHs}$ and the amount of SW generated at the $\mathrm{HH}$ level have a positive correlation as shown in Figure 3. That means as the number of family members' increases, the amount of SW generated increases. However, the 
study also showed that an increase in family size may not necessarily increase the amount of MSW generated at $\mathrm{HH}$ level. This might be due to the contribution of other factors such as socioeconomic status of HHs that can increase or decrease the amount of SW generated at $\mathrm{HH}$ level.

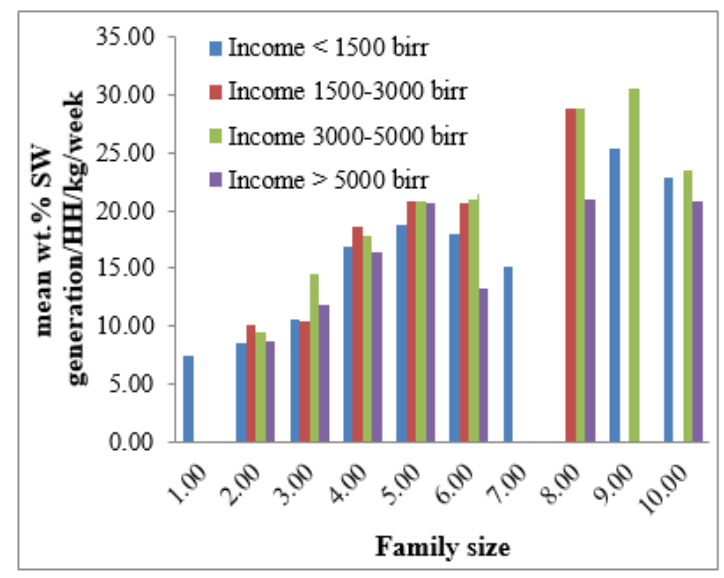

Fig 3: Relationship between family income and size with amount of SW generated

Relationship between family income and amount of SW generated at HH level: As shown in Figure 3, those HHs with medium income group (income between 1500-5000) generated more SW than HHs with income $<1500$ and $>5000$ added together. This suggested that family income level and another socioeconomic status of residents can affect the amount of SW generated at the $\mathrm{HH}$ level. The lowest amount of SW was generated in the low-income group HHs (income $<1500$ ).

Chemical Characterization of the $S W$ : The chemical characteristics of SW are essential in determining the efficiency of solid waste treatment process. So in this study, chemical characterizations were carried out after homogenizing the MSW sample following the Mexican Standard Test Method "NMX-AA-0151985" (SCOFI 1985c).

Density, $p H$ and Fusing Point of the $S W$ : The density of the SW was calculated from its mass which is obtained in a pre-weighed wooden cube. The $\mathrm{pH}$ of the SW sample was measured using a HANNA pH 211 Microprocessor $\mathrm{pH}$ meter. The fusing point of ash was measured by heating the SW sample in a muffle furnace. Table 5a shows the $\mathrm{pH}$, density $\left(\mathrm{kg} / \mathrm{m}^{3}\right)$, and fusing point of MSW.

Table 5a: Results of the $\mathrm{pH}$, density $\left(\mathrm{kg} / \mathrm{m}^{3}\right)$, and fusing point of MSW

\begin{tabular}{llllll}
\hline Parameters & Mean & Minimum & Maximum & STDEV & Mean \pm STDEV \\
\hline Density & 613.22 & 613.18 & 613.26 & 0.04 & $613.22 \pm 0.04$ \\
pH & 10.66 & 10.65 & 10.66 & 0.01 & $10.66 \pm 0.01$ \\
Fusing Point & 965 & 960 & 970 & 5.00 & \pm 5.00 \\
\hline
\end{tabular}

Proximate Analysis: Proximate analysis was done to determine the moisture content, volatile matter content, ash content and fixed carbon content using ASTM Standard Test Method. Moisture content determination became feasible after 24 hours of SW sample drying at a temperature of $105{ }^{\circ} \mathrm{C}$ in an oven (type JouanEU2 118, Innovens). For the determination of volatile matter and ash content of SW sample, a furnace capable of producing a temperature high up to $1200{ }^{\circ} \mathrm{C}$ (type L24/12 with control panel B170, Nabertherm) was used. Table $5 \mathrm{~b}$ shows the proximate of MSW and its calorific value. Ash is the inorganic residue that leftovers after fixed carbon burning. Ash content is influential in transport, handling and overall process costs of MSW. In this study, the MSW have relatively high ash content $(32.03 \%)$ that makes it unsuitable for use as a solid fuel. The moisture content of the MSW ranged from 25.4 to $25.70 \%$ and indicated that the MSW contains high moisture content that might facilitate the dissolution of organic and inorganic chemical compounds and hence increases the leaching of these compounds to the environment. This value is also in agreement with the moisture content of MSW (20-30\%) in Europe and America (MENG A., et al., 2012). The MSW have relatively low volatile matter content that ranged from 28.07 to $28.11 \%$. Volatile matters have a strong effect on the thermal decomposition of the MSW. So low volatile contents MSW requires high temperature to be ignited. Fixed or non-combined carbon (FC) is the portion remaining after the volatile matter is completely released, apart from ash and moisture, produced a char and it was burned as a solid substance in the combustion process. It was obtained by calculation from $\% \mathrm{MC}, \% \mathrm{VM}$ and $\% \mathrm{AC}$ and it was found to be $14.37 \%$ by dry weight basis.

\begin{tabular}{llllll}
\multicolumn{7}{c}{ Table 5b: Results of Proximate Analysis $(\mathrm{n}=3)$} \\
\hline Variables & Mean & Minimum & Maximum & STDEV & Mean \pm STDEV \\
\hline \%(w/w)Ash & 32.03 & 32.00 & 32.05 & 0.02 & $32.03 \pm 0.02$ \\
$\%(w / w) M C$ & 25.57 & 25.4 & 25.70 & 0.15 & $25.57 \pm 0.15$ \\
$\%(w / w) V M$ & 28.09 & 28.07 & 28.11 & 0.02 & $28.09 \pm 0.02$ \\
$\%(w / w) F C$ & 14.37 & 14.19 & 14.5 & 0.16 & $14.32 \pm 0.16$ \\
\hline
\end{tabular}


Determination of Heavy Metal: The determination of heavy metals such as $\mathrm{Cu}, \mathrm{Pb}, \mathrm{Zn}, \mathrm{Co}, \mathrm{Cd}$, and $\mathrm{Cr}$ in MSW was carried out using Buck Scientific, Model 210 VGP Atomic absorption spectrophotometer using ASTM Standard Test Method. The mean concentrations of the selected heavy metals concentration are shown in Figure 4.

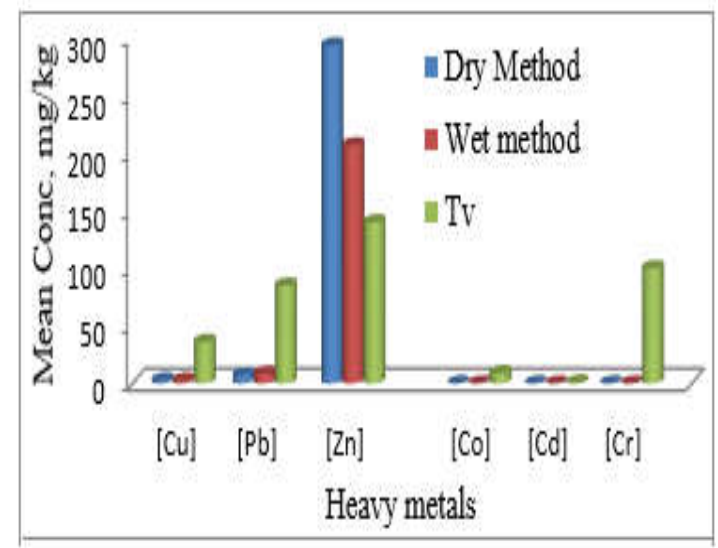

Fig 4: The elemental composition of MSW sample

As shown in Figure 6, the concentration of Zinc in the MSW sample exceeded the level of Dutch Pollutant Standard to reach an eco-toxicological risk (Bird et al. 2003). The tremendous concentration of $\mathrm{Zn}$ in the MSW sample may be related to the high quantity of this metal in the waste composition that is disposed of in the landfill (Calace et al. 2001) from primary sources such as ash, kitchen waste and paper components of the early waste (Long et al., 2011) and this might result in broader contamination by leachate migration. In contrast, the accumulation of $\mathrm{Cu}$ and $\mathrm{Pb}$ in the MSW was found to be lower than the target value standards. But the accumulation of these metals may be elevated by long term accumulation (Kejeldsen et al. 2002). The concentration of cadmium and chromium were found to be below the detection limit of the instrument.

Conclusion: The study has shown that the amount of MSW generated per HH in Sawla town municipality is largely affected by family size and socioeconomic status of HHs. In addition, most of the MSW generated in the town was composed of food-organic waste, ash and dust that could be reused as compost. Furthermore, leachates from MSW landfill might contribute to environmental pollution and health problem near the surrounding area as it is indicated by high levels of zinc in the MSW.

Acknowledgements: We would like to express our gratitude to Hawassa University and Sawla town administration for supporting the research.

\section{REFERENCES}

Afewerk, B; Beneberu, S (2015). Household Solid waste generation rate and Composition, and people's attitude towards its management in Gambella Town, Western Ethiopia. Haromaya University.

Alemayehu, A (2007). Hand Book on General Principles to Solid Waste Management. Mega Publishing Enterprise, Addis Ababa.

Standard Test Method for Determination of the composition of Unprocessed Municipal Solid waste (ASTM). ASTM Standard D 5231-5292 (Reapproved 2003). American Society for Testing and Materials US.

Bird, G; Brewer, PA; Macklin, MG; Balteanu, D; Driga, B; Serban, M; Zaharia, S (2003). The solid state portioning of contaminant metals and as in river channel sediments of the mining affected Tisa drainage basin, north western Romania and eastern Hungari. Applied Geochemistry. 18:1583 $-1595$.

Birke, Y (1999). Solid Waste Management in Ethiopia. Paper presented in the Integrated Development for Water Supply and Sanitation, Addis Ababa.

Butterworth, H (2003). Hand book of solid waste management and waste minimization Technologies. 337 - 465 .

Calace, N; Liberatori, A; Petronio, BM; Pietroletti, M (2001). Characteristics of different molecular weight fractions of organic matter in landfill lichate and their role in soill sorption of heavy metals. Environmental Pollution. 113:331 - 339.

CEC (1977). Second EC Environment Action Programme (1977-81). Commission of the European Communities, Brussels. https://ec.europa.eu/environment/archives/soil/pd f/SEC 2006_620.pdf

Degnet, A (2003). Determinants of Solid Waste Disposal Practices in Urban Areas of Ethiopia: A Household-level Analysis. Project Muse Scholarly Journals. Ethiopian Economic Association/Ethiopian Economic Policy Research Institute, vol. xxiv (1), Addis Ababa, Ethiopia. Environmental Protection Authority (EPA) (2004). State of Environment Report for Ethiopia. Addis Ababa. 
Francisco, DM (2018). Waste management in developed and developing countries: The case study of Umbria (Italy) and the west bank (Palestine). DETRITUS. 03: 171 - 180.

Gebrie, K (2009). Management of Domestic Solid Waste in Bahirdar Town: Operational Analysis and Assessment of Constraints that Affect Solid Waste Management, Addis Ababa, Ethiopia.

Henry, RK; Yongsheng, Z; Jun, D (2006). Municipal Solid Waste Management Challenges in Developing Countries- Kenyan Case Study, Waste Management 26.

Karak, T; Bhagat, RM; Pradip, BP (2012). Municipal Solid Waste Generation, Compositon, and Management: The World Scennario. Journal of Critical Reviews in Environmental Science and Technology. 42(15).

Kejeldsen, P; Barlaz, MA; Rooker, AP; Baun, A; Christensen, TH (2002). Present and long term composition of MSW landfill leachate: Crit. Rev. Environ. Sci. Technol. 32(4):297 - 336.

Lema, A (2007). Household solid waste generation rate and composition analysis in two selected kebles of Adama town, MSc thesis paper, Addis Ababa University. Addis Ababa, Ethiopia.

Longa, YY; Shena, DS; Wang, HT; Lub, WJ; Zhao, Y (2011). Heavy Metal Source Analysis in Municipal Solid Waste (MSW): A case Study on $\mathrm{Cu}$ and $\mathrm{Zn.} \mathrm{J} \mathrm{Hazard.} \mathrm{Mat.} \mathrm{186(2-3):1082} \mathrm{-} 7$.

MENG, A; Qinghai, LI; Jinyan, JIA; ZHANG, Y (2012). Effect of Moisture on Partitioning of Heavy Metals in Incineration of Municipal Solid Waste. Chinese J. Chem. Engineer. 20(5): 1008 1015 .

Petts, J; Edulijee, G (1994). Environmental Impact Assessment for Waste Treatment. Chichester, John Wiley and Sons.
Rushbrook, P; Pugh, M (1999). Solid Waste Landfills in Middle and Lower Income Countries. A Technical Guide to Planning, Design, and Operation. The World Bank, Washington. U.S.A.

SECOFI (1985c). Norma Mexicana NMX-AA-0521985.Protección al ambiente-contaminación del suelo residues sólidos municipales-preparación de muestrasen el laboratorio para suanálisis. Secretaría de Comercio y Fomento Industrial.Dirección General de Normas. 18 de Marzo de 1985.

Simon, AM (2008). Analysis of Activities of Community Based Organizations Involved in Solid Waste Management, Investigation Modernized Mixtures Approach. The Case of Kinondoni Municipality Dare Salaam. MSc Thesis, Wageningen University.

Solomon, C (2011). Assessment of Municipal Solid Waste Management service in Dessie Town, Addis Ababa University, Ethiopia.

Srinivas, R (2003). State of the environment report and action plan, Karnataka.

Suocheng, D; Tong, K; Yuping, Y (2001). Municipal solid waste management in China: using commercial management to solve a growing problem. Utilities Policy. 10: 7 - 11.

Tchobanoglous, G; Theisen, H; Vigil, S (1993). Integrated Solid Waste: Engineering Principles and Management issues. McGraw-Hill Publishing Company, USA.

United Nation Environment Programme (UNEP) (1996). International Source Book on Environmentally Sound Technologies for Municipal Solid Waste Mamagement. UNEP Technical Publicaion. Tokyo, Japan.

United Nations Environment Programme (UNEP) (2005). Solid Waste Management (Volume II: Regional Overviews and Information Sources). 